\title{
Regional Innovation Development as a Feature of Competitiveness in the XXI Century
}

\author{
Irina S. Zinovyeva', Yuri A. Kozenko², Kirill B. Gerasimov³ , Yulia I. Dubova4', Margarita S. Irizepova²
}

\begin{abstract}
The authors of this paper hypothesize that one of the most significant features of regional competitiveness in the global economy is innovation development and that through innovation application, underdeveloped regions can reduce the gap between them and leading regions and can in turn surpass leading regions. The purpose of the article is to verify this hypothesis, to determine the role and significance of innovation development in the provision of regional competitiveness and to identify ways to increase the competitiveness of underdeveloped regions through innovation application. The methodological basis of the research is comprised of a specially developed proprietary methodology for the evaluation of regional competitiveness and a modified factor analysis methodology for the determination of factors of regional economic growth using the "economic miracle" case for various regions. Through this study, the authors validate the proposed hypothesis and conclude that innovation development critically shapes regional competitiveness by determining the quality of economic growth. The proposed model for increasing regional competitiveness on the basis of innovation development presents new opportunities to increase the competitiveness of underdeveloped regions through innovation application.
\end{abstract}

KEY WORDS: innovation development, regional economies, competitiveness

JEL Classification: $\quad$ O32, F630

${ }^{1}$ Voronezh State University of Forestry and Technologies named after G.F. Morozov, Russia; ${ }^{2}$ Volgograd State University, Russia; ${ }^{3}$ Samara National Research University, Russia; ${ }^{4}$ Volgograd State Technical University, Russia

\section{Introduction}

In the XXI century, competition has risen to a whole new level. Currently, not only specific enterprises but also entire countries compete with one another. They compete for access to resources - human, material, and capital - for sales markets of manufactured

Correspondence concerning this article should be addressed to: Kirill B. Gerasimov, Samara National Research University; 34 Moscow HWY, Samara, 443086, Russian Federation. T: 79-27-204-4019. E-mail: 270580@bk.ru products, for investments into the development of regional businesses, etc. This competition is global in nature, and thus, neighboring countries presenting similar peculiarities form regions that are subjects of global competition and that act on behalf of all countries that form them.

The most competitive regions become leaders in the global economy. They form coalitions and initiate strong relations with investors, further strengthening their competitiveness. These regions develop dynamically and boast strong quality of life 
standards, and this in turn attracts highly qualified specialists from the entire world and leads to the accumulation of significant intellectual capital in these regions.

Meanwhile, regions that are less competitive struggle to become suppliers of raw materials and centers for the sale of products to leading regions. Presented no opportunities for development, underdeveloped regions stagnate and lose their competitiveness. As a result of low living standards, the most qualified specialists who offer the most intellectual capital form migration flows and gradually leave these regions (Popkova, Yurev, Stepicheva, \& Denisov, 2015).

Despite the obvious advantages of leadership in the global economy, the most competitive regions are not interested in having other regions lag behind, as high levels of differentiation in regional economic development lead to the growth of global tensions, crisis phenomena, violations of economic ties, uncontrolled migration from underdeveloped to developed regions, etc.

This is why not only underdeveloped regions but also leading regions are interested in aligning levels of economic development across regions. This will require increasing the competitiveness of underdeveloped regions. This article presents the scientific hypothesis that one of the most significant factors affecting regional competitiveness in the global economy is innovation development and that through innovation application, underdeveloped regions can close the existing gap and surpass leading regions. The purpose of this article is to verify the presented hypothesis, to determine the role and meaning of innovation development for regional competitiveness and to identify ways to increase to competitiveness of underdeveloped regions through innovation application.

\section{Literature review}

The theoretical basis of the present study lies in the works of modern scientists focused on regional economies. An analysis of previous studies published in this discipline shows that several works have been published on regional development, including studies by (Li, Cheng, \& Wu, 2016; Malikov, Sharipova, Kharisov, Sunaeva, \& Mukhametova, 2015; Zarubin, Tkhakushinov, Kuizheva, Nekrasova, \& Ovsyanniko- va, 2015; Zinovyeva, 2015). A regional economy is the economic system of a specific region within a national economy (Meléndez, Borges-Mendez, Visser, \& Rosofsky, 2015). The study of regional economic development is necessary for the successful planning of territorial economic organization (Solodilova, Malikov, \& Grishin, 2015). Under current economic conditions, regions can be independent subjects acting in national and international markets (Tsathlanova, Idzhilova, \& Erdnieva, 2015).

Scientific studies have focused on principles and facets of global competition. Such works include (Cerna \& Chou, 2014; Choi, 2013; Demedts, 2015; Docquier \& Machado, 2016; (Hartmann, 2014; Kim \& Urpelainen, 2015; Miyagiwa \& Sato, 2014; Sung, 2015). Through the internationalization of economic relations, global competition has evolved over recent decades (Demedts, 2015) as enterprises, regions, and countries have struggled to access resources and sales markets of manufactured products at the international scale (Hartmann, 2014). Such global competition is rooted in limited resources and sales markets (Miyagiwa \& Sato, 2014). As new members become involved in international trade, global competition continues to grow.

An important collection of these studies focuses on regional competitiveness in the global economy. Such works include (Guerrero, Urbano, \& Fayolle, 2014; Huggins, Izushi, Prokop, Thompson, 2014; Kamalova \& Polovkina, 2014; Komarova, Zjablova, \& Denmukhametov, 2014; Ženka, Novotný, \& Csank, 2014) The competitiveness of a region in the global economy is determined based on its capacities to provide high living standards (Gallyamova, 2014), to attract investment resources (, and to effectively use the economic potential of the region for the manufacturing of goods and services (Kirshin \& Kuzminov, 2014).

Issues of regional innovation development have recently been studied in the following works: (Kropelnytska \& Vusyatytska, 2015; Makkonen \& Inkinen, 2015; Ng, Kanagasundram, Wong, \& Chandran, 2015; Sadyrtdinov, Korablev, \& Vladimirova, 2015; Salamonsen, 2015; Schwerdtner, Siebert, Busse, \& Freisinger, 2015; Yakovleva, Azarova, \& Titova, 2015). Regional innovation development is the most important condition for regional global competitiveness ( $\mathrm{Za}$ - 


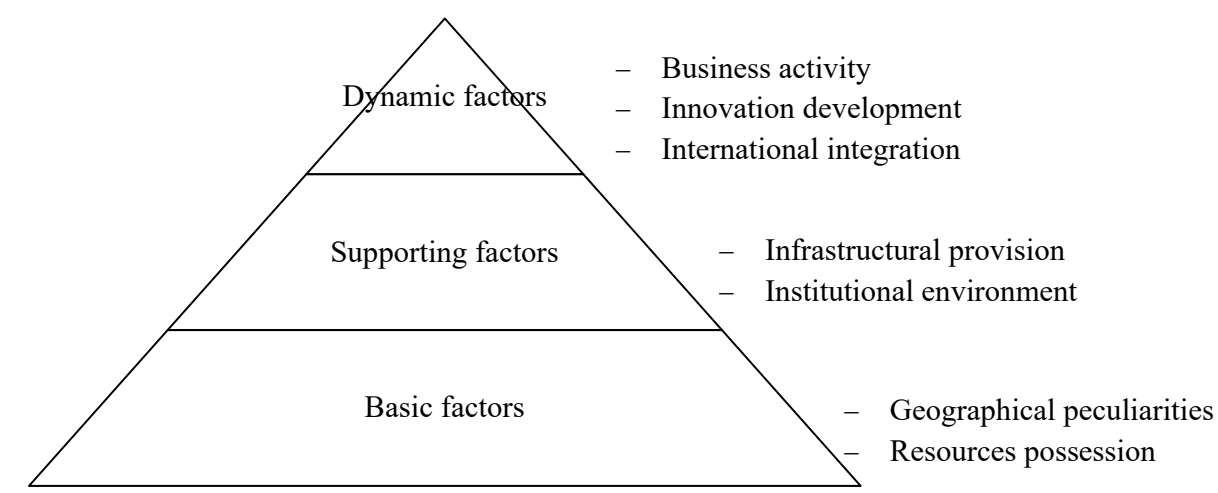

Figure 1. Pyramid of factors of regional competitiveness

rubin \& Tkhakushinov, 2014). Regional innovation development involves the development of process, organizational, or technological innovations (Vaz, de Noronha Vaz, Galindo, \& Nijkamp, 2014) and their application in production activities of the enterprises of a region for the generation of innovation products (Baimbetova, 2013).

However, despite the numerous studies conducted in the sphere of regional development, most are fragmented and focus on specific features of regional competitiveness. There is currently no scientific proof of the existence of a causal relationship between various factors and levels of regional competitiveness. There is also no theoretical or methodological basis for increased regional competitiveness, creating the necessity to conduct further research in this area. This paper addresses these gaps.

\section{Method}

The following scientific methods are applied: induction, deduction, analysis, synthesis, and formalization. The methodological basis of the present study is also related to special methods of scientific research used in the sphere of economic theory.
In particular, this work uses a specially developed proprietary methodology for the evaluation of regional competitiveness. The international productive specialization of a region determines its targeted markets and competitiveness factors as follows (Fisher, Perekrestova, \& Lomakina, Irizepova, 2014):

- natural, climatic, geographic, and ecological features of a region;

- the possession of resources (natural resources - cheap and available raw materials, human resources - cheap or high-quality human resources, capital resources - accessibility of financial sources, i.e., credit and investment, resources);

- regional business activities;

- development of infrastructural provisions of business activities and correspondence to international norms and standards;

- quality and development of regional institutional environments;

- levels of international integration and regional cooperation, which determines levels of involvement in global economic processes occurring in the global economy; and

- levels of regional innovation development. 
Table 1. Methods of evaluation of regional competitiveness

\begin{tabular}{|c|c|c|c|}
\hline \multirow{2}{*}{$\begin{array}{l}\text { Factors of regional } \\
\text { competitiveness }\end{array}$} & \multicolumn{2}{|c|}{ Indicators of regional competitiveness } & \multirow{2}{*}{ Indicator weights } \\
\hline & Model region & This region & \\
\hline \multicolumn{4}{|c|}{ Basic factors } \\
\hline Geographical peculiarities & 1.00 & GP & 0.3 \\
\hline Resources possession & 1.00 & RP & 0.7 \\
\hline Index of base (IB) & 1.00 & $\mathrm{IB}=\left(\mathrm{GP}^{*} 0.3+\mathrm{RP} * 0.7\right) / 2$ & - \\
\hline \multicolumn{4}{|c|}{ Supporting factors } \\
\hline Infrastructural provision & 1.00 & IP & 0.5 \\
\hline Institutional environment & 1.00 & $\mathrm{IE}$ & 0.5 \\
\hline Support index (SI) & 1.00 & $\mathrm{SI}=\left(\mid \mathrm{P}^{*} 0.5+\mathrm{IE}^{*} 0.5\right) / 2$ & - \\
\hline \multicolumn{4}{|c|}{ Dynamic factors } \\
\hline Business activity & 1.00 & BA & 0.3 \\
\hline Innovation development & 1.00 & ID & 0.5 \\
\hline International integration & 1.00 & $\|$ & 0.2 \\
\hline Index of dynamics (ID) & 1.00 & $\mathrm{ID}=\left(\mathrm{BA} * 0,3+\mathrm{ID}^{* *} 0.5+\|^{*} 0.2\right) / 3$ & - \\
\hline $\begin{array}{l}\text { Integral indicator of regional } \\
\text { competitiveness }(\mathrm{Cl})\end{array}$ & 1.00 & $C l=(B A+|P+| D) / 3$ & - \\
\hline
\end{tabular}

The stated features of regional competitiveness can be grouped in the following way:

- basic factors: geographic peculiarities and resources;

- supporting factors: infrastructural provisions and institutional environments; and

- dynamic factors: business activities, innovation development, and international integration.

This grouping of factors is determined by regional management opportunities. Factors form a pyramid composed of basic factors that form initial peculiarities of a given region. In the middle of the pyramid, there are supporting factors that create a basis for regional development. The top of the pyramid includes dynamic factors that are the most active and flexible (Fig. 1).

According to the given classification, factors are added to the table. The method for evaluating regional competitiveness involves comparing indicators of regional competitiveness on given factors with values of the modeled region. Consolidated indices are calculated as groups of factors (basis, support and dynamics indexes) based on the arithmetic average of the product of weighted factor values.

As a result, the integral indicator of regional competitiveness is calculated as the arithmetical average of all indices (Table 1). The retrieved integral indicator of regional competitiveness is compared to the value for the modeled region and constitutes a certain percentage of this value, allowing one to identify differences between regions.

The methodology is advantageous in its universality for determining the competitiveness of various regions, for comparing retrieved values, for conducting simple calculations, and for the quick receipt of evaluation results. The methodology is slightly limited 
Table 2. Summary of regional competitiveness factors

\begin{tabular}{|c|c|c|c|c|c|}
\hline $\begin{array}{l}\text { Factors of regional } \\
\text { competitiveness }\end{array}$ & $\begin{array}{l}\text { Place as to } \\
\text { region }\end{array}$ & $\begin{array}{c}\text { Duration of } \\
\text { influence }\end{array}$ & $\begin{array}{l}\text { Power of } \\
\text { influence }\end{array}$ & $\begin{array}{l}\text { Manageability } \\
\text { of influence }\end{array}$ & $\begin{array}{c}\text { Type of caused } \\
\text { effect }\end{array}$ \\
\hline \multicolumn{6}{|c|}{ Basic factors } \\
\hline Geographical peculiarities & internal & long-term & low & uncontrolled & simple effect \\
\hline Resources possession & Internal & long-term & medium & $\begin{array}{c}\text { poorly } \\
\text { controlled }\end{array}$ & $\begin{array}{l}\text { multiplication } \\
\text { effect }\end{array}$ \\
\hline \multicolumn{6}{|c|}{ Supporting factors } \\
\hline Infrastructural provision & internal & mid-term & high & $\begin{array}{l}\text { highly } \\
\text { controlled }\end{array}$ & $\begin{array}{l}\text { multiplication } \\
\text { effect }\end{array}$ \\
\hline Institutional environment & internal & mid-term & high & $\begin{array}{l}\text { highly } \\
\text { controlled }\end{array}$ & $\begin{array}{l}\text { multiplication } \\
\text { effect }\end{array}$ \\
\hline \multicolumn{6}{|c|}{ Dynamic factors } \\
\hline Business activities & internal & short-term & medium & $\begin{array}{c}\text { poorly } \\
\text { controlled }\end{array}$ & simple effect \\
\hline Innovation development & internal & short-term & high & $\begin{array}{l}\text { moderately } \\
\text { controlled }\end{array}$ & synergetic effect \\
\hline International integration & internal/external & short-term & low & $\begin{array}{l}\text { moderately } \\
\text { controlled }\end{array}$ & $\begin{array}{l}\text { multiplication } \\
\text { effect }\end{array}$ \\
\hline
\end{tabular}

in its use of expert evaluations for assigning values to indicators, ascribing a certain degree of subjectivity to the final results.

The method also involves using a modified factor analysis approach for determining factors of regional economic growth based on the "economic miracle" case for various regions. Based on expert evaluations, the values of regional competitiveness factors in provisioning "economic miracle" conditions for each region are determined and assigned values of 1 (the smallest contribution) to 10 (the largest contribution).

\section{Results}

Factors of regional competitiveness differ on various attributes: by region, the duration of effects, the power of effects, the manageability of effects, and types of effects creating peculiarities (Table 2). Table 2 shows that all factors relate to each region, and only the factor of international integration is partially external, as it concerns the involvement of international representatives. Effects (determining the speed of effect changes) last over the long term for basic factors, over the medium term for supporting factors and over the short term for dynamic factors.

The influence of geographic factors is the least significant, while the influence of institutional, infrastructural, and innovation factors is the most significant. Resource and business factors are poorly controlled, while geographical factors are uncontrolled. Innovation development and international integration are of average manageability, and infrastructural and institutional factors are highly manageable.

Geographic and business factors have simple effects, meaning that their effects do not extend beyond the limits of this sphere of the economy. Resource, infrastructural, institutional, and integra- 
Table 3. Summary of factors of "economic miracle" of various regions

\begin{tabular}{lccc}
\hline Factors of regional competitiveness & Japanese miracle & Chinese miracle & Italian miracle \\
\hline Geographic peculiarities & 1 & 1 & 3 \\
Resources possession & 2 & 2 & 1 \\
\hline & Supporting factors & 4 & 3 \\
\hline Infrastructural provision & 3 & 3 & 4 \\
Institutional environment & 4 & 3 & 4 \\
\hline Business activities & Dynamic factors & 5 & 3 \\
\hline Innovation development & 4 & 4 & 3 \\
\hline International integration & 5 & 4 & 5 \\
\hline
\end{tabular}

Note: Adapted from (Testa, 2015; Tillack, 2015; Yang \& Zhao, 2015)

tion factors have multiple effects, meaning that their effects are felt in other spheres of the economy. Only innovation factors have synergetic effects, meaning that they can qualitatively influence the entire economic system of a given region, highlighting their importance.

Let us conduct a factor analysis of "economic miracle" conditions for various regions using the cases of Japan, China, and Italy (Table 3). From the results of our factor analysis, it is possible to conclude that the factor contributing most to the economic growth of various regions is innovation development. This was determined by assigning weights to various indicators while evaluating regional competitiveness.

The Japanese economic miracle involved a historical phenomenon of record growth in the Japanese economy that began in the mid-1950s and that lasted until the oil crisis of 1973. Annual economic growth during this economic miracle period amounted to almost $10 \%$, and rates were the highest among the most developed countries of the period. The "miracle" was spurred by low taxes and by the intensive scientific development of new technologies in Japan, which did not reach Japan before World War II due to isolation policies imposed by authorities.
The Chinese economic miracle involved a period of economic reform in China lasting from 19781997, when the gross domestic product of the country grew 5.7-fold and 9.6\% annually. GDP grew at a record speed every 7.5 years. The Italian economic miracle involved a period of rapid domestic economic growth occurring from the mid-1950s to the mid-1970s. During this period, the economy of the country evolved from agrarian to industrial and into one of the most heavily industrialized economies in the world, rendering the country a global leader. This economic growth was rooted in the widespread modernization of production.

This proves that innovation development is one of the most important features of regional competitiveness. Therefore, increasing the competitiveness of underdeveloped regions requires innovation application. Let us conduct an evaluation of the competitiveness of the Eastern European, Asian, and African regions using the proposed methodology (Table 4).

Table 4 shows that the Eastern European region keeps pace with the North American region on basic indicators but is less strong with respect to supporting and dynamic factors. The integral indicator of the competitiveness of the Eastern European region is 
Table 4. The results of the competitiveness evaluation

\begin{tabular}{|c|c|c|c|c|}
\hline \multirow{2}{*}{$\begin{array}{l}\text { Factors of regional } \\
\text { competitiveness }\end{array}$} & \multicolumn{4}{|c|}{ Indicators of regional competitiveness } \\
\hline & $\begin{array}{l}\text { North American } \\
\text { region ("model") }\end{array}$ & $\begin{array}{c}\text { East European } \\
\text { region }\end{array}$ & Asian region & African region \\
\hline \multicolumn{5}{|c|}{ Basic factors } \\
\hline Geographical peculiarities & 1.00 & 1.00 & 0.40 & 0.30 \\
\hline Resources possession & 1.00 & 1.00 & 0.60 & 0.50 \\
\hline Base index (BI) & 1.00 & 1.00 & 0.27 & 0.22 \\
\hline \multicolumn{5}{|c|}{ Supporting factors } \\
\hline Infrastructural provision & 1.00 & 0.30 & 0.60 & 0.20 \\
\hline Institutional environment & 1.00 & 0.30 & 0.40 & 0.10 \\
\hline Index of support (IS) & 1.00 & 0.30 & 0.50 & 0.15 \\
\hline \multicolumn{5}{|c|}{ Dynamic factors } \\
\hline Business activity & 1.00 & 0.50 & 0.50 & 0.10 \\
\hline Innovation development & 1.00 & 0.40 & 0.60 & 0.10 \\
\hline International integration & 1.00 & 0.90 & 0.70 & 0.80 \\
\hline Index of dynamics (ID) & 1.00 & 0.18 & 0.20 & 0.08 \\
\hline $\begin{array}{l}\text { Integral indicator of regional } \\
\text { competitiveness }(\mathrm{Cl})\end{array}$ & 1.00 & 0.49 & 0.32 & 0.15 \\
\hline
\end{tabular}

valued at 0.49 . Rather, its competitiveness value is half that of the global leader

The Asian and African regions are substantially weaker than the North American region on all factors. Integral competitiveness indicators of 0.32 and 0.15 , respectively, were found. That is, the global leader's competitiveness is three times stronger that of the Asian region and seven times stronger than that of the African region. The following factors hinder innovation development in underdeveloped regions most:

- limited scientific and educational development;

- underdeveloped patent systems and complex innovation copyright registration systems;

- limited connections between science and business;

- lacking investment resources for the implementation of innovational projects;

- weak state support for enterprise innovation activities; and
- high-risk components of innovation projects due to the unpredictability of economic conditions.

The following are presented as ways to address such problems and to create conditions for innovation development in underdeveloped regions:

- develop innovation business infrastructure;

- create strong institutional bases for the creation and application of innovations in processes of production;

- increase the investment attractiveness of given regions;

- encourage state facilitation of enterprise innovation activities; and

- forge strong relations between scientific and business sectors.

As a way to direct underdeveloped regions onto innovative paths of development, this research proposes 


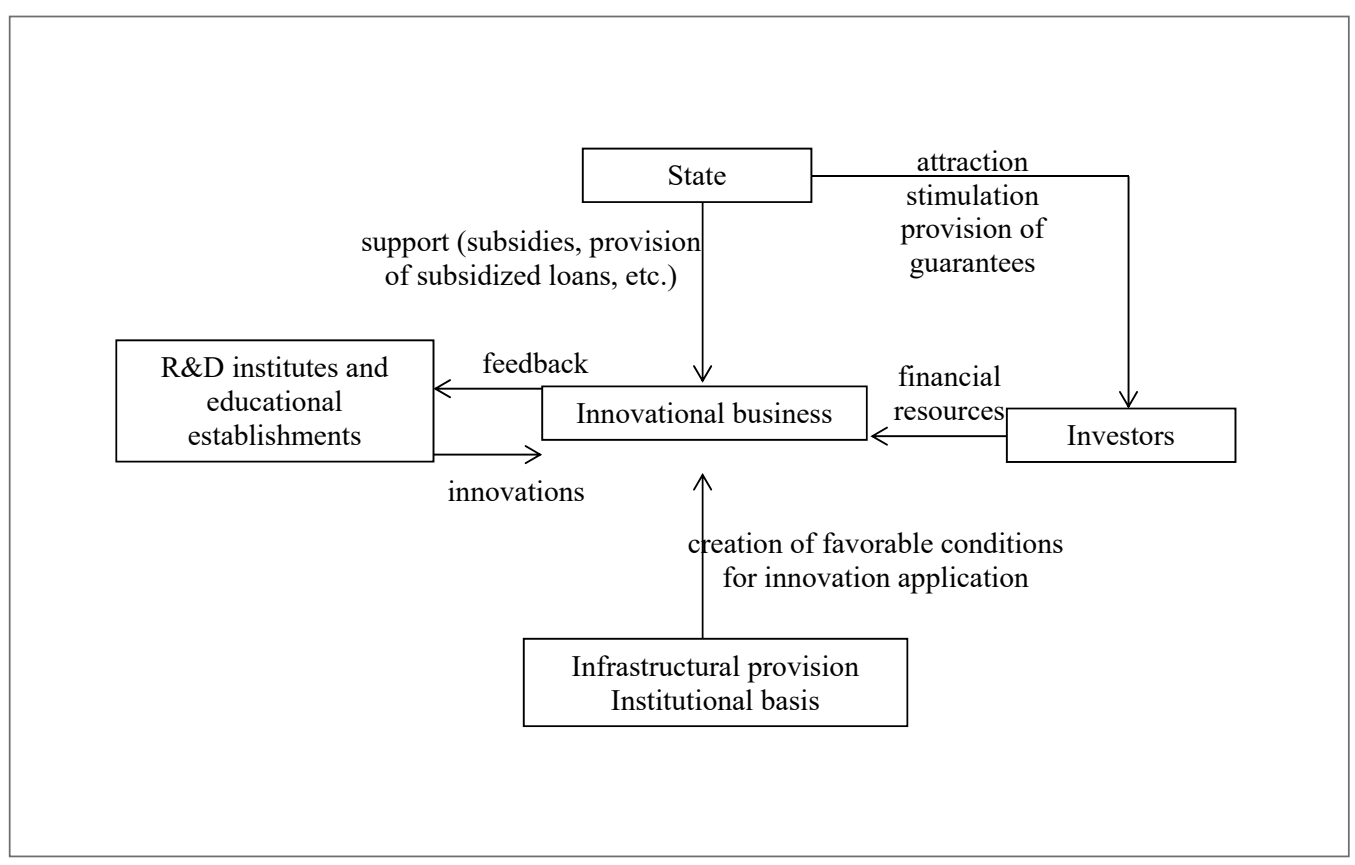

Figure 2. Model of increasing regional competitiveness on the basis of innovation development

using the developed model to boost regional competitiveness via innovation development, in turn allowing for the application of our recommendations (Fig. 2).

Fig. 2 shows that the majority of the increase in regional competitiveness on the basis of innovation development is attributable to innovation entrepreneurship, which is actively supported by states and investors, closely related to R\&D institutes and educational establishments, and offers necessary infrastructural provisions and strong institutional bases from which to create favorable conditions for innovation application.

\section{Conclusion}

Through the present study, the proposed hypothesis was proven. It was determined that one of the most significant factors shaping regional competitiveness in the global economy is its degree of innovation development and that through innovation application, underdeveloped regions can reduce the gap with and even surpass leading regions, as proven through the experiences of countries experiencing "economic miracles."
It is thus possible to conclude that innovation development occupies an important place in the provision of regional competitiveness, as it determines the quality of economic growth. The proposed model for increasing regional competitiveness on the basis of innovation development broadens opportunities to increase the competitiveness of underdeveloped regions through innovation application.

It should be noted that when applying the proposed model, it is necessary to pay special attention to the management of risks related primarily to the realization of innovational projects; to long periods of investment returns; to the unpredictability of results; and to opposition to business, societal, and state innovations, which are manifestations of inclinations towards traditions and toward the preservation of stability.

Despite the universality of the proposed methodology in evaluating regional competitiveness and its representation in quantitative form, the method is limited by subjectivities that reduce the precision of research results generated. Future research conducted in this area should thus involve the development 
of fully objective methodologies for the evaluation of regional competitiveness on the basis of specific statistical indicators.

It should be noted that under conditions of global regional competition, constant development is needed to preserve positioning in global markets. While global leaders are presented with ample opportunities for innovation application and creation, this does not mean that other regions cannot improve their positioning in the global economy. Innovations are key to reducing the gap between developed and developing countries and to balancing the global economy.

\section{References}

Baimbetova, A. A. (2013). Innovations as a major factor in the socio-economic development of Kazakhstan in the global competition. World Applied Sciences Journal, 27, 24-27.

Cerna, L., Chou, M. H. (2014). The regional dimension in the global competition for talent: Lessons from framing the European Scientific Visa and Blue Card. Journal of European Public Policy, 21(1), 76-95.

Choi, Y. J. (2013). The Global Financial Crisis Revisited: Competition and Regulation. Global Economic Review, 42(4), 362-381.

Demedts, V. (2015). Which future for competition in the global trade system: Competition chapters in FTAs. Journal of World Trade, 49(3), 407-436.

Docquier, F., \& Machado, J. (2016). Global competition for attracting talents and the world economy. World Economy, 39(4), 530-542.

Fisher O. V., Perekrestova L. V., \& Lomakina T. P. Irizepova, M. S. (2014). Оценка эффективности налогового стимулирования инновационной деятельности в России [Evaluation of effectiveness of tax stimulation of innovational activities in Russia]. Налоги $и$ налогообложение [Taxes and taxation], 2(103), 156-173.

Gallyamova, D. (2014). Cluster policy as a tool of regional economics competitiveness improvement. Economic Annals-XXI, 3-4(1), 12-15.

Guerrero, M., Urbano, D., \& Fayolle, A. (2016). Entrepreneurial activity and regional competitiveness: evidence from European entrepreneurial universities. The Journal of Technology Transfer, 41(1), 105-131.
Hartmann, E. (2014). The fetish of global competition. Capital and Class, 38(1), 184-196.

Huggins, R., Izushi, H., Prokop, D., \& Thompson, P. (2014). Regionalna konkurentnost, gospodarski rast i faze razvoja [Regional competitiveness, Economic growth and stages of development]. Zbornik Radova Ekonomskog Fakultet au Rijeci, 32(2), 255-283.

Kamalova, A. A., \& Polovkina, E. A. (2014). Regional aspect of value added use in assessing competitiveness of economic districts. Mediterranean Journal of Social Sciences, 5(24), 24-27

Kim, S. E., \& Urpelainen, J. (2015). Rising regional powers meet the global leader: A strategic analysis of influence competition. International Political Science Review, 36(2), 214-234.

Kirshin, I. A., \& Kuzminov, S. V. (2014). Evaluation method development for regional economies competitiveness. Mediterranean Journal of Social Sciences, 5(18), 159-164.

Komarova, V. N., Zjablova, O. V., \& Denmukhametov, R. R. (2014). An infrastructure factor in regional competitiveness. Mediterranean Journal of Social Sciences, 2(1), 355-360.

Kropelnytska, S., Vusyatytska, M. (2015). Institutional and financial support for regional innovation development based on cluster approach. Economic Annals-XXI, 3-4(2), 37-40.

Li, Z., Cheng, J., \& Wu, Q. (2016). Analyzing regional economic development patterns in a fast developing province of China through geographically weighted principal component analysis. Letters in Spatial and Resource Sciences, 9(3), 233-245.

Makkonen, T., Inkinen, T. (2015). Geographical and temporal variation of regional development and innovation in Finland. Fennia, 193(1), 134-147.

Malikov, R. I., Sharipova, I. M., Kharisov, V. I., Sunaeva, G. G., \& Mukhametova, D. D. (2015). Development of assessment tools for economic activity of regional business. Mediterranean Journal of Social Sciences, 6(5), 434-444.

Meléndez, E., Borges-Mendez, R., Visser, M. A., \& Rosofsky, A. (2015). The restructured landscape of economic development: Challenges and opportunities for regional workforce development collaborations. Economic Development Quarterly, 29(2), 150-166. 
Miyagiwa, K., Sato, Y. (2014). Free entry and regulatory competition in a global economy. Journal of Public Economics, 118, 1-14.

Ng, B. K., Kanagasundram, T., Wong, C. Y., Chandran, V. G. R. (2015). Innovation for inclusive development in Southeast Asia: The roles of regional coordination mechanisms. Pacific Review, 29(4), 573-602.

Popkova, E. G., Yurev, V., Stepicheva, O., Denisov, N. (2015). Transformation and concentration of intellectual capital as a factor of economic growth in the modern economy. Regional and Sectoral Economic Studies, 15(1), 53-60.

Sadyrtdinov, R. R., Korablev, M. M., Vladimirova, S. A. (2015). Regional innovation system development: Comparative analysis of the Republic of Tatarstan and Volga Federal District Regions. Mediterranean Journal of Social Sciences, 6(1), 317-321.

Salamonsen, K. (2015). The effects of exogenous shocks on the development of regional innovation systems. European Planning Studies, 23(9), 17701795.

Schwerdtner, W., Siebert, R., Busse, M., \& Freisinger, U. B. (2015). Regional open innovation roadmapping: A new framework for innovation-based regional development. Sustainability, 7(3), 23012321.

Solodilova, N. Z., Malikov, R. I., \& Grishin, K. Y. (2015). Potential for development and limitations of regional business environment. Economy of Region, 42(2), 137-148.

Sung, T. K. (2015). The creative economy in global competition. Technological Forecasting and Social Change, 96, 89-91.

Testa, C. (2015). La nuova Italia del Miracolo Economico: 'Un disco per l'estate' mezzo secolo fa [The new Italy of economic miracle: "A drive for summer" half a century ago]. Forum Italicum, 49(2), 674-676.

Tillack, P. (2015). Concrete abstractions: Gotô meisei's hapless danchi dwellers and Japan's economic miracle. Positions, 23(2), 231-257.

Tsathlanova, T. T., Idzhilova, D. V., \& Erdnieva, E. V. (2015). The problem-oriented analysis of regional cluster policy development in the Russian Federation. Mediterranean Journal of Social Sciences, 6(4), 333-339.
Vaz, E., de Noronha Vaz, T., Galindo, P.V., \& Nijkamp, P. (2014). Modelling innovation support systems for regional development - analysis of cluster structures in innovation in Portugal. Entrepreneurship and Regional Development, 26(1-2), 2346.

Yakovleva, E. A., Azarova, N. A., Titova, E. V. (2015). Innovation as a vector of regional economic development and a necessary condition for the progress of the world economy. Asian Social Science, 11(20), 90-96.

Yang, H., Zhao, D. (2015). Performance legitimacy, state autonomy and China's economic miracle. Journal of Contemporary China, 24(91), 64-82.

Zarubin, V. I., Tkhakushinov, E. K. (2014). Management of innovation development system of regional economic: Project approach. World Applied Sciences Journal, 30(2), 191-194.

Zarubin, V. I., Tkhakushinov, E. K., Kuizheva, S. K., Nekrasova, S. O., \& Ovsyannikova, T. A. (2015). Conceptual specific of project management of regional economy development. Asian Social Science, 11(14), 306-313.

Ženka, J., Novotný, J., \& Csank, P. (2014). Regional competitiveness in Central European Countries: In search of a useful conceptual framework. European Planning Studies, 22(1), 164-183.

Zinovyeva, A. A. (2015). The development of regional management by smoothing of spatial polarization. Asian Social Science, 11(11), 253-258. 